\title{
Identification of the population source of free-ranging cats threatening endemic species on Tokunoshima Island, Japan
}

\author{
Kazuaki Kazato ${ }^{1,2} \cdot$ Yuya Watari $^{3}$ (I) $\cdot$ Tadashi Miyashita $^{1}$ (D)
}

Received: 27 May 2020 / Accepted: 17 August 2020 / Published online: 25 August 2020

(C) The Author(s) 2020

\begin{abstract}
Free-ranging cats Felis silvestris catus are harmful to endemic species, especially on islands. Effective management practices require an understanding of their habitat use and population source at the landscape level. We aimed to identify the source of the free-ranging cat population on Tokunoshima Island, Japan, which harbors a variety of endemic organisms as well as human settlements. Trapping data for the whole island were provided by local governments, and landscape factors (residential, agricultural, and woodlot areas and cattle barn density) affecting cat density were explored. An analysis of live-capture data indicated that the density (per $1 \mathrm{~km}^{2}$ ) of free-ranging cats was positively correlated with the densities of cattle barns and woodlot areas and negatively correlated with residential areas. An interview survey revealed that nearly half of the cattle barns feed free-ranging cats. The source habitat of free-ranging cats appears to be areas with a high density of cattle barns and a high percentage of woodlots in human-dominated landscapes. Feeding cats in cattle barns may strengthen the bottom-up process of population growth on the island. To reduce the impact of cats on endemic species on Tokunoshima Island, efforts to stop feeding cats in cattle barns are important. Reaching a consensus with stakeholders will require further studies of the ecological risks posed by free-ranging cats.
\end{abstract}

Keywords Felis silvestris catus $\cdot$ Habitat selection $\cdot$ Invasive species management $\cdot$ Hyper-predation

\section{Introduction}

Invasive alien species are major drivers of global biodiversity loss. In particular, exotic mammals are responsible for $58 \%$ of species extinctions worldwide (Doherty et al. 2016). Invasive predator management is urgently required for the conservation

Communicated by: Krzysztof Schmidt

Electronic supplementary material The online version of this article (https://doi.org/10.1007/s13364-020-00528-5) contains supplementary material, which is available to authorized users.

Yuya Watari ywatari@affrc.go.jp

1 Laboratory of Biodiversity Science, School of Agriculture and Life Sciences, The University of Tokyo, 1-1-1 Yayoi, Bunkyo-ku, Tokyo 113-8657, Japan

2 Present address: NIPPON KOEI Co., Ltd., 5-4 Kojimachi, Chiyoda-ku, Tokyo 102-8539, Japan

3 Forestry and Forest Products Research Institute, 1 Matsunosato, Tsukuba-shi, Ibaraki 305-8687, Japan of biodiversity (Butchart et al. 2010; Mack et al. 2000; McGeoch et al. 2010; Doherty et al. 2017).

Free-ranging domestic cats Felis silvestris catus (including outdoor pet cat, stray cats and feral cats; see Spotte 2014) are one of the most successful invasive species, being established throughout the world, causing a detrimental impact on native species in areas from islands to continents (Bonnaud et al. 2011; Medina et al. 2011; Nogales et al. 2013; Courchamp et al. 2003; Woinarski et al. 2017; Woolley et al. 2019; Kays et al. 2020). In particular, the impact of predation on native species by cats is serious on islands where no predatory mammals were historically present (Bonnaud et al. 2011; Medina et al. 2011; Nogales et al. 2013; Courchamp et al. 2003), contributing to the extinction of at least 63 vertebrate taxa (Loss and Marra 2017). Other issues related to free-ranging cats include the transmission of infections, such as toxoplasmosis and toxocariasis (Deplazes et al. 2011; Macpherson 2013; Gerhold and Jessup 2013; Lepczyk et al. 2020; Wilson et al. 2020) or hybridization with the wildcat (Felis silvestris) (Pierpaoli et al. 2003).

To reduce the impacts of free-ranging cats, management strategies have been implemented mainly in Europe, the 
USA, and Oceania and include the use of poison bait, shooting, trapping, TNR (trap, neuter, and return), and fencing (Campbell et al. 2011; Courchamp et al. 2003; Foley et al. 2005; Ringma et al. 2019). In Japan, trapping and TNR are the main approaches used on islands, such as the Ogasawara Islands, Amami Islands, Okinawa Island, Iriomote Island, and Teuri Island, where endemic species are impacted by cats (Nagamine 2011; Kagoshima Environmental Studies Program 2019). Some local municipalities on Japanese islands have recently established guidelines for breeding and restrictions on cat feeding (Kagoshima Environmental Studies Program 2019), but local residents and protection groups frequently oppose these guidelines and cat management, as reported in many countries (Lilith et al. 2006; Oppel et al. 2011; Marra and Santella 2016).

The management of cat populations generally requires information on the source habitat and the factors limiting the target population (Moseby et al. 2009). Free-ranging cats often depend on anthropogenic resources, such as feeding by humans and garbage, except in natural areas where humans have little access (Doherty et al. 2014; Pillay et al. 2018; Kays and Dewan 2004). However, most studies have focused on habitat use in relatively small areas with a small number of individuals, and so little is known about population sources at wide spatial scales (but see Flockhart et al. 2016). Therefore, the identification of population source and key resources for cat populations may help to establish alternatives to temporary treatments, such as TNR, for more effective management, such as the prohibition of feeding cats and keeping cats indoors (Trouwborst et al. 2020).

Tokunoshima Island is located in the Ryukyu Archipelago in southwestern Japan. Many endemic species and subspecies evolved here in the absence of native mammalian predators (Maeda et al. 2019). This island is a region of great importance for biodiversity conservation and has been nominated for the World Natural Heritage List (Ministry of the Environment 2018). However, predation on endemic species by freeranging cats is becoming a serious problem. For example, food items of free-ranging cats on this island included threatened Amami rabbit Pentalagus furnessi (IUCN red list category: EN), Ryukyu long-haired rat Diplothrix legata (EN), Tokunoshima spiny rat Tokudaia tokunoshimensis (EN), Ryukyu robin Erithacus komadori komadori (VU), and Amami tip-nosed frog Odorrana amamiensis (VU) (Maeda et al. 2019).

As a result, cat management has been conducted since 2014 to conserve endemic fauna. Because it is difficult to discriminate general classification of free-ranging cats (i.e., outdoor pet, stray, and feral cats; e.g. Spotte 2014) from their appearance, the management program on Tokunoshima Island classifies free-ranging cats by their capture locations. Cats caught in human-dominated landscapes are conveniently identified as "stray cats" and are returned to the wild after sterilization (TNR) because it is implicitly assumed that they do not enter the forest nor prey on endemic species. Cats caught in forest landscapes are conveniently identified as "feral cats" and are kept in shelters after sterilization and occasionally transferred to new owners. However, a recent study revealed that "feral cats" preying on endangered species in the forest were mostly dependent on cat food, as revealed by a stable isotope analysis representing long-term food habits of animals (Maeda et al. 2019). In addition, recaptures of TNR individuals between "stray cats" $(18.6 \%)$ and "feral cats" (14.6\%) were similar (Maeda et al. 2019). These results indicate that convenient classification of free-ranging cats on this island makes little sense, and both "stray" and "feral" cats appear to have a risk to endemic species. In addition, the source of a population of free-ranging cats is most likely located in the human-dominated areas, from which the cats frequently move to the forested areas, resulting in human-driven hyper-predation on endemic endangered species. Therefore, it might be difficult to eliminate free-ranging cats unless the subsidization of their source by humans is controlled. In this situation, beyond the operational discrimination of "stray cats" and "feral cats," identifying population source of freeranging cats would be an essential approach to make consensus building with local residents and resolve problems associated with invasive cats on this island.

In this study, we aimed to identify the population source of the free-ranging cats in human-dominated landscapes by examining the factors determining the distributions of freeranging cats. To evaluate this, a multiple regression analysis was performed using wide-scale capture data for free-ranging cats provided by local governments combined with land use data. Next, an interview survey was conducted with owners of cattle barns to clarify the extent to which they feed freeranging cats, because cattle barns were identified as most possible sites maintaining free-ranging cats on Tokunoshima Island from our multiple regression analysis.

\section{Methods}

\section{Study site}

Tokunoshima Island $\left(27^{\circ} 45^{\prime} \mathrm{N}, 128^{\circ} 58^{\prime} \mathrm{E}\right)$ is located in the Ryukyu Archipelago in southwestern Japan (Fig. 1a) and is divided into three towns: Tokunoshima, Amagi, and Isen. The island has an area of $248 \mathrm{~km}^{2}$ and a population of about 24,000 persons (Kagoshima Prefecture 2019). Tokunoshima Island is in a subtropical region with high precipitation (mean temperature, $21.6{ }^{\circ} \mathrm{C}$, mean annual rainfall, $1912 \mathrm{~mm}$ ) (Kagoshima Prefecture 2019). Primary industry workers account for about $30 \%$ of the total population on Tokunoshima Island (Kagoshima Prefecture 2019). Agricultural land covers $27.8 \%$ of the total area, most of which is used to grow potatoes 
and sugarcane (Kagoshima Prefecture 2019). Taking advantage of the warm climate, cattle production is active. Approximately $34 \%$ of agricultural production is calf production, with about 1000 livestock farm households on the island (Agriculture and Livestock Industry Promotion Organization 2019). Similar to a report in Portugal (Ferreira et al. 2011), we frequently observed cats in cattle barns on Tokunoshima Island. Therefore, cattle barns may create a population source of the free-ranging cat on this island. Forest area covers $42.5 \%$ of the island and is dominated by evergreen oaks such as Castanopsis sieboldii and Quercus miyagii (Kagoshima Prefecture 2019). Tokunoshima Island was separated from the Eurasian continent approximately 2 million years ago and is home to many endemic species (Ota 1998). Additionally, venomous snakes such as the habu snake Protobothrops flavoviridis account for about 30 human bites annually (Kagoshima Prefecture 2018) and are a major cause for concern among local residents.

The three local governments and the Ministry of the Environment began capturing free-ranging cats in 2014 to conserve endemic species. "Stray cats" (i.e., cats caught in human-dominated landscapes such as residential area, agricultural area, and woodlots remaining in residential and agricultural areas) are returned to the wild after sterilization (TNR) and ear-tipped to identify sterilized individuals by the local Tokunoshima Island government. "Feral cats" (i.e., cats caught in forest landscapes) are kept in shelters after sterilization with a potential transfer to new owners. Between 2014 and 2017, 2612 "stray cats" were released by TNR operation and 235 "feral cats" were removed (Maeda et al. 2019).

\section{Trap capture data}

Capture records of "stray cats" by metal box traps were provided by the three local Tokunoshima Island governments. As described earlier and in Maeda et al. (2019), all "stray cats" were captured in human-dominated landscapes. Records of trap installation locations and working days are available from April 2018 to August 2019. The number of captured adult cats and the number of trap days (TD) at a $1-\mathrm{km}$ mesh over the whole island were obtained, where data were available. To avoid duplicate counting, cats previously captured and marked (ear-tipped individuals) were excluded, and only first captured adult cats were included. The number of captured individuals adjusted by trap working days (referred to as catch per unit effort: CPUE) was used as a density index for analyses.

\section{Land use and spatial variables}

To determine the landscape structures affecting the distribution of free-ranging cats, the percentages of residential, agricultural, and woodlot areas and the number of cattle barns were calculated in each $1-\mathrm{km}$ mesh. Land cover data were obtained from the Geospatial Information Authority of Japan website, and the above percentage areas were calculated using ArcGIS 10.6 (ESRI Japan). Here, woodlot refers to an area occupied by evergreen broad-leaved trees and pine trees, which remains fragmented in human-dominated landscapes. Land cover data were summarized by the first two axes in a principal component analysis (PCA), and principal component scores were calculated for each mesh. The cattle barn locations were partially modified from the locations provided by Minami-Oshima Agricultural Mutual Aid. Spatial autocorrelation in variables was calculated to consider possible spatial effects larger than the mesh scale. Moran's eigenvector maps (MEM) were constructed based on the 2-dimensional spatial coordinates (Legendre and Legendre 2012). The five MEM axes (MEM1-MEM5) representing spatial structures were extracted using the Delaunay triangulation method, and MEM scores were calculated for each mesh using the R package "adespatial."
Fig. 1 a Map of Tokunoshima Island, with a spatial land use. b Spatial distribution of the numbers of captured individuals adjusted by trapping efforts (CPUE: captures/trap days) at $1-\mathrm{km}$ mesh scale over the whole island a

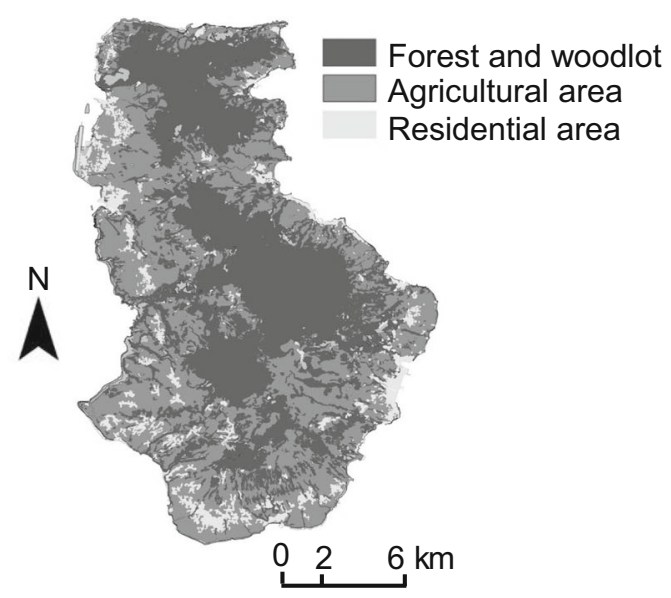

b

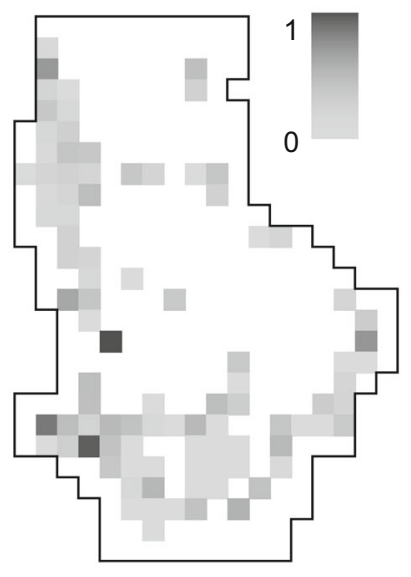




\section{Statistical analysis}

For the analysis of trapping data provided by local governments, meshes with at least $10 \mathrm{TD}$ were used. A generalized linear model (GLM) with a negative binomial distribution was used to investigate the relationship between the density of free-ranging cats and land use. The response variable was the number of trapped cats and the explanatory variables were PC1, PC2, cattle barn density, and MEM1 to MEM5, with an offset term (Faraway 2006) accounting for TD at each mesh. The offset term makes it possible to standardize the number of captured individuals by trapping effort (CPUE). The model with the best performance was selected using a multi-model inference approach. The "MuMIn" implemented in the R package was used to produce all subsets of models based on the global model and these were ranked based on the Akaike information criterion (AIC). Model averaging was used to generate the averaged parameter estimates of all models with $\triangle \mathrm{AIC}<2$.

\section{Interview survey}

We conducted an interview survey to cattle farmers over the whole island to evaluate the extent to which cats in cattle barns are fed. We adopted face-to-face interviews instead of distributing questionnaires, because the percent of replies would be expected to be quite low by sending questionnaires. We conducted interviews wherever possible taking the opportunity of veterinarians' visiting farmers for regular diagnostics of cattle. The farmers were asked whether they feed free-ranging cats or not and if so, how many cats are fed. We also obtained the number of breeding cattle as a proxy for cattle barn size. The relationship between the number of cats fed and breeding cattle was tested with Pearson's correlation coefficient $(r)$.

\section{Results}

\section{Distribution of free-ranging cats in the human-dominated landscape}

We obtained trapping records at $971-\mathrm{km}$ meshes from April 2018 to August 2019, of which 69 meshes with trapping effort over $10 \mathrm{TD}$ were used in this analysis. In these meshes, a total of 462 cats (excluding recaptured individuals) were captured by 6086 trapping days. On average, the number of captured cats and trapping days were 6.7 cats and 88.2 TD per mesh, respectively, which resulted in the average CPUE (cats/TD) of 0.08 , with a range of $0-1.0$ (Fig. 1b). The spatial distribution of the number of captured cats, TD, and the number of recaptured cats are shown in Supplementary Appendix 1.

PCA for the land cover data showed that the first (PC1) and second (PC2) axes in combination explained $95 \%$ of the total variance. The variable of residential areas loaded positively on PC1, while woodlot areas loaded negatively (Fig. 2a). Agricultural areas loaded negatively on PC2 (Fig. 2b). The spatial distributions of $\mathrm{PC} 1$ and $\mathrm{PC} 2$ are shown in Supplementary Appendix 2. The correlation coefficients for the relationship between cattle barn density and these principal component scores were small (PC1: $r=$ 0.363 , PC2: $r=-0.389$ ), indicating no serious collinearity problem.

Model averaging for GLM revealed that the number of cats caught per trapping effort was positively correlated with cattle barn density (Fig. 3, Fig. 4) and negatively correlated with PC1, MEM1, and MEM3 (Fig. 3). This indicates that the density of free-ranging cats is high where there are many cattle barns and woodlots in human-dominated landscapes and low where residential areas predominate. The significant correlation with MEM1 indicates that free-ranging cats are more common in the southwest than in northwestern areas (Fig. 5). Similarly, the effect of MEM3 indicates the presence of further spatial structure in northwestern areas (Fig. 5). Because there were no correlations between TNR implementation and any of the above environmental variables (cattle barn density: $r=-0.101$, PC1: $r=0.163$, MEM1: $r=-$ 0.234 , MEM3: $r=-0.038$ ), the spatial variation in cat density cannot be explained by TNR-mediated declines.

\section{Interview surveys}

Seventy-one farmers out of 130 cattle barns visited answered our interview survey. About $45 \%$ (32/71) of the cattle farms examined fed free-ranging cats, and these cattle farms were scattered over the island (Supplementary Appendix 3). There was no relationship between the number of cats fed and the cattle barn size $(r=0.09, t=0.65, d f=48, p=0.52)$.

\section{Discussion}

We obtained two major findings concerning the distribution of free-ranging cats on Tokunoshima Island: (1) free-ranging cat density in human-dominated landscapes increases as the cattle barn density and woodlot area increase and (2) free-ranging cats are frequently fed in cattle barns. These results suggest that feeding by humans could have significantly contributed to establishing a large population of free-ranging cats on Tokunoshima Island. As free-ranging cats are known to depend on human-subsidized food while foraging on endemic mammals (Maeda et al. 2019), an increase in free-ranging cats in human-dominated landscapes may result in spillover of free-ranging cats to the forested area, thereby affecting endemic species. We name this process "human-driven hyper-predation" after hyper-predation, in which the bottom-up effect of the introduced prey increases the abundance of the introduced 
Fig. 2 The factor loadings of landscape elements for PC1 (a) and PC2 (b), obtained by principal component analysis of landscape variables a

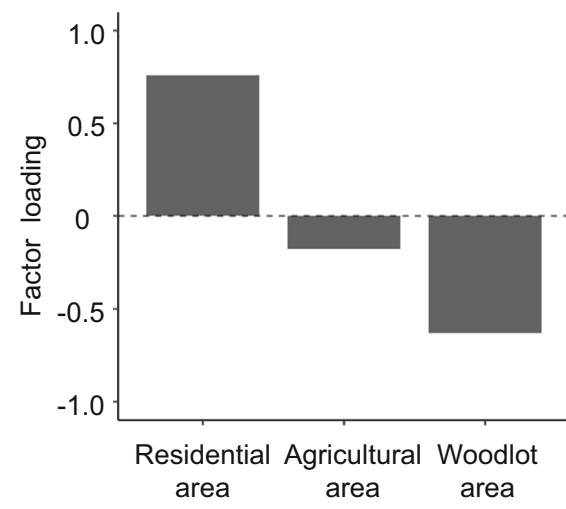

b

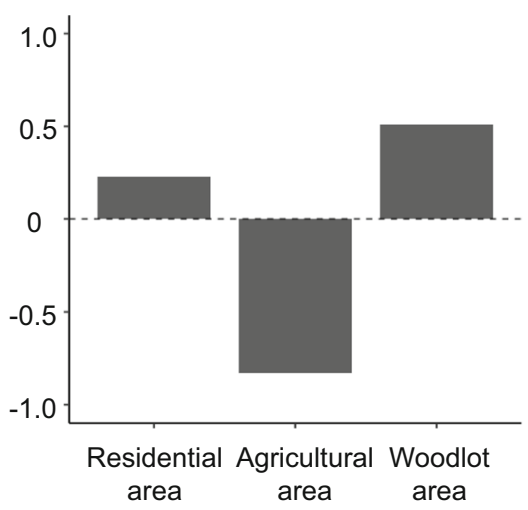

predator, thereby increasing predation pressure on the native prey (Courchamp et al. 2000).

\section{Population source of free-ranging cats}

Using broad-scale capture data for human-dominated landscapes, we detected a positive relationship between the densities of cats and cattle barns. Several studies have reported that free-ranging cats were frequently observed in cattle barns (Ferreira et al. 2011; Horn et al. 2011), but few populationlevel analyses have been performed. Several mechanisms are proposed for the increase of cats in cattle barns: (1) feeding by people (Barratt 1997; Ferreira et al. 2011; Piquet et al. 2019) and (2) high natural prey availability, such as alien rats (Rattus rattus) and passerine birds gathering to feed on cattle food, and water availability (Rosario et al. 2015; Leirs et al. 2004). Our interview survey revealed that free-ranging cats are fed in

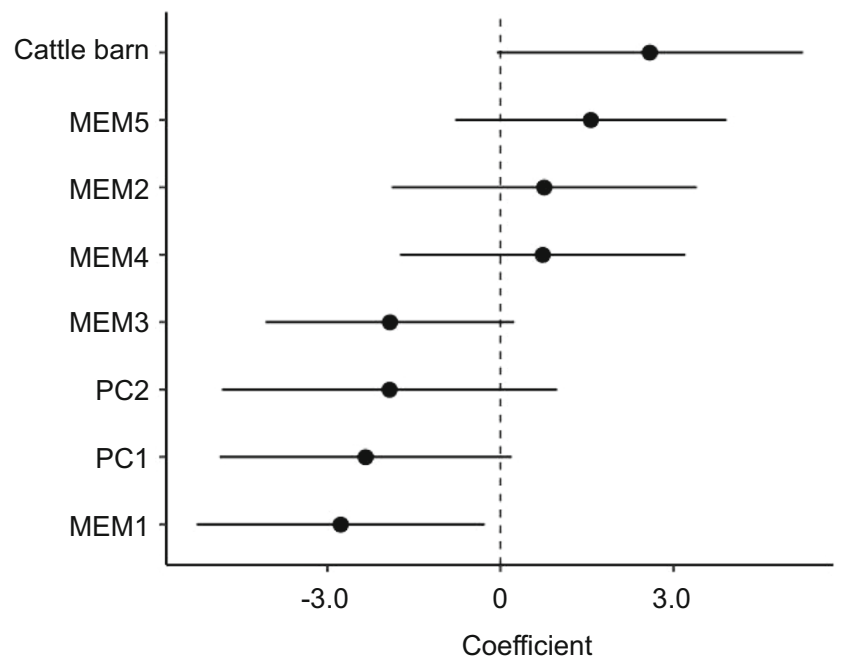

Fig. 3 The coefficients of the variables that explain CPUE (catch per unit trapping effort) of cats, which were obtained by model averaging of GLM (generalized linear models). Values are the mean $\pm 95 \% \mathrm{CI}$ (confidence interval). MEMs represent Moran's eigenvector maps on the island and PCs represent the first two axes in a principal component analysis (PCA), summarizing land cover data
$45 \%$ of the cattle barns examined. Therefore, feeding cats by people is likely to be the main factor for creating a population source of free-ranging cats on this island.

We also found that free-ranging cats are more abundant in areas with higher woodlot areas but lower residential areas. This is contrary to the findings that there are many freeranging cats in residential areas (Doherty et al. 2014; Morin et al. 2018), where food resources from settlements are abundant (Tennent and Downs 2008; Vincent et al. 2018). However, on Tokunoshima Island, rural communities have fixed garbage collection days (twice a week), and garbage is deposited outdoors and picked up by collectors on the same morning, providing limited access to food by cats. Another explanation is that sufficient resources from feeding by humans decreased the capture efficiency by traps. However, this seems unlikely because areas with a high cattle barn density had a higher CPUE, where feeding by humans is common. The positive effect of woodlot areas remaining in residential areas (PC1) may be due to the availability of resting

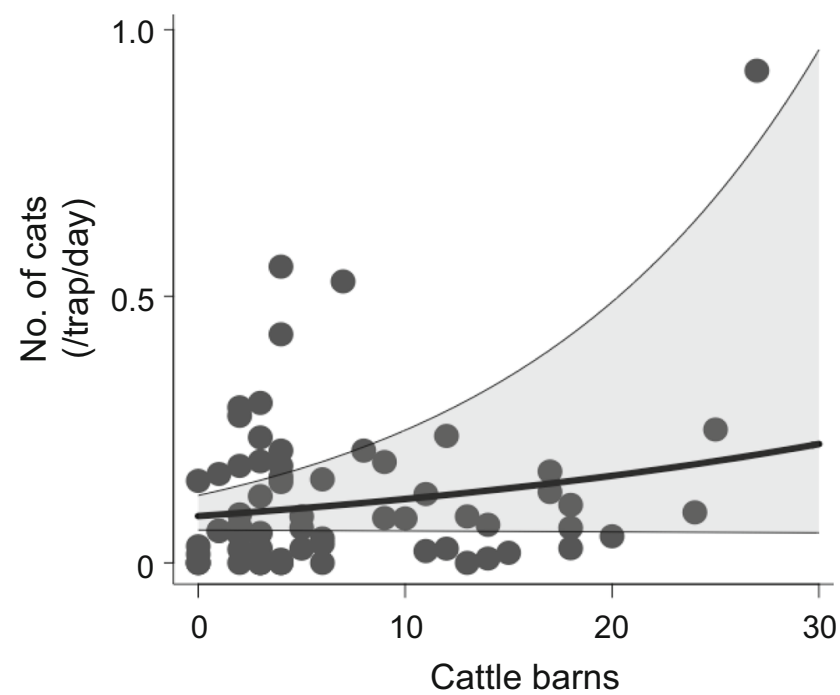

Fig. 4 Relationship between cattle barn density and CPUE (number of cats captured per unit trapping effort) at the $1-\mathrm{km}$ mesh scale. The gray area represents the $95 \%$ confidence interval of the simple regression line 
Fig. 5 The spatial distributions of the scores of 1 st and 2nd axes of Moran's eigenvector maps (MEM) on the island. Large squares represent high MEM scores, and white and black squares indicate positive and negative scores, respectively
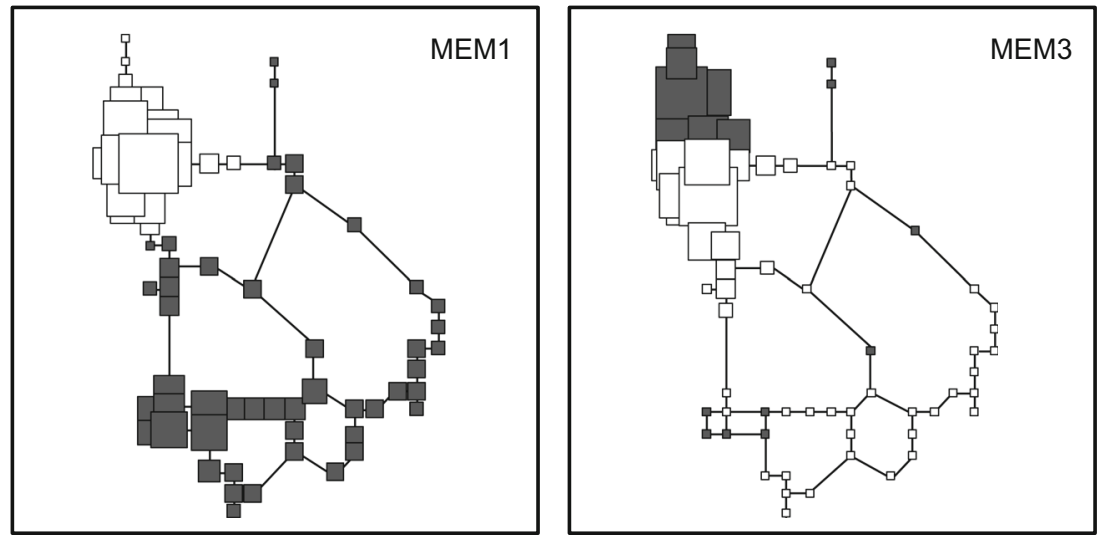

sites and/or natural food resources, such as arthropods and introduced rats.

Of note, the negative association between cat density and MEM1 demonstrated a spatial pattern much larger than the 1$\mathrm{km}$ mesh scale. MEM1 indicates a density gradient in which free-ranging cats increase from the northwest to the southwest. The reason for this trend is not clear, but factors important at smaller scales may be scaled-up to the broader gradient via the spatial clumping of landscape elements. Although there is no clear difference in barn density between the northwest and southwest, landscape structures appear to be different. In the northwest, there are more residential areas with small woodlot areas in the human-dominated landscape, but the opposite trend is found in the southwest, which may have created the density gradient.

\section{Management implications and future issues}

Tokunoshima Island has been nominated for the World Natural Heritage List, and invasive species management is an important requirement for this designation (Ministry of the Environment 2018). The cat problem on this island is closely linked to the unique and complex interactions between social and ecological systems. The cattle industry has flourished for the last 50 years. Furthermore, farmers believe (as we were informed during our surveys) that cats reduce the number of venomous snakes by controlling the population of alien rats that are also the main prey of the snakes. This appears to have facilitated the increase in the free-ranging cat population across the island, thereby threatening endemic species in forests.

In recent years, the abundance of endemic species has gradually increased, while that of cats observed in the forested areas has decreased with progress in the management of "feral cats" on Tokunoshima Island (Sawanobori 2019). However, given the continual invasion of cats from human-dominated areas, it seems difficult to maintain populations of endemic species unless the bottom-up effects of supporting freeranging cats by human-supplied resources are controlled
(Maeda et al. 2019). Based on our results, it is important to stop feeding cats in cattle barns, but further studies are necessary to gain consensus with the people feeding cats. For example, it is necessary to quantify the risks of zoonotic diseases transmitted by free-ranging cats to both livestock and humans (Tenter et al. 2000). It is also necessary to clarify whether freeranging cats actually contribute to the reduction of introduced rat populations and hence reduce the number of venomous snakes. Alternative methods for rat control that do not rely on free-ranging cats should also be considered. Poison bait is a widely used and generally reliable method with little impact on non-target species (Capizzi et al. 2014; Brown et al. 2006), but its effect on the endemic Tokunoshima spiny rat in forests should be carefully assessed. More systematic and quantitative questionnaires concerning the background reasons for feeding cats are also required to examine what types of information (e.g., ecological impact of cats, risks of zoonoses, and actual contribution of cats as biological control agent) is more effective for changing behavior of people feeding cats.

Forest landscapes are not the main habitat of free-ranging cats on Tokunoshima Island. However, in areas where humandominated landscapes (especially cattle barns) are close to forest landscapes (i.e., where both are included in a cat home range), cats can freely move between both landscapes and could therefore impact endemic species. Actually, our preliminary surveys using GPS collars showed that the range of maximum travel distance by cats captured in humandominated landscapes was $0.5-12 \mathrm{~km}$, and half of the cats entered forested areas within those periods (Kazato et al. unpublished data). In the northern part of the island, humandominated and forest landscapes are relatively close, and spillover from the human-dominated landscape to the forest landscape may be frequent. In these areas, cat management should be strongly prioritized.

The results of this study suggest that feeding free-ranging cats in cattle barns is an important support for free-ranging cats, which induces bottom-up effects on their population. Additional capture data that include age and reproductive information of individuals will enable us to estimate the 
population parameters of free-ranging cats, providing a basis for quantitative evaluations of the role of cattle barns to their reproduction and survival and the development of effective capture programs to reduce the free-ranging cat population.

Acknowledgments We are grateful to T. Maeda and Qi Huiyuan for their collaboration in the early stages of this work. We would like to thank R. Sawanobori and the members of the NPO Tokunoshima Nijinokai, the Tokunoshima Cat Management Council for their hospitality during my visit. We would also like to thank K. Kimura for his help attending.

Authors' contributions Y. Watari and T. Miyashita designed the concept and Y. Watari managed the project. K. Kazato conducted field research and analysis. K. Kazato, Y. Watari, and T. Miyashita interpreted the results. K. Kazato made manuscript with critical revisions by Y. Watari and T. Miyashita. All authors approved the final version for publication.

Funding information This research was supported by the Environment Research and Technology Development Fund (JPMEERF20184004) of the Environmental Restoration and Conservation Agency of Japan and JSPS KAKENHI Grant Number JP 1K19868.

\section{Compliance with ethical standards}

Conflict of interest The authors declare that they have no conflict of interest.

Ethics approval Y. Watari completed the ethical course of Human Subjects Research authorized by the Association for the Promotion of Research Integrity (course completion report no. AP0000017354).

Consent to participate Not applicable.

\section{Consent for publication Not applicable}

Open Access This article is licensed under a Creative Commons Attribution 4.0 International License, which permits use, sharing, adaptation, distribution and reproduction in any medium or format, as long as you give appropriate credit to the original author(s) and the source, provide a link to the Creative Commons licence, and indicate if changes were made. The images or other third party material in this article are included in the article's Creative Commons licence, unless indicated otherwise in a credit line to the material. If material is not included in the article's Creative Commons licence and your intended use is not permitted by statutory regulation or exceeds the permitted use, you will need to obtain permission directly from the copyright holder. To view a copy of this licence, visit http://creativecommons.org/licenses/by/4.0/.

\section{References}

Agriculture and Livestock Industry Promotion Organization (2019) Cattle breeding management on a remote island -a case study of Shota Shige, a young livestock farmer in Tokunoshima Island, Kagoshima Prefecture-. https://www.alic.go.jp/joho-c/joho05 000661.html. Accessed: 12 March 2020. (in Japanese)

Barratt DG (1997) Home range size, habitat utilisation and movement patterns of suburban and farm cats Felis catus. Ecography 20:271280. https://doi.org/10.1111/j.1600-0587.1997.tb00371.x
Bonnaud E, Medina FM, Vidal E, Nogales M, Tershy B, Zavaleta ES, Donlan CJ, Keitt BS, Corre ML, Horwath SV (2011) The diet of feral cats on islands: a review and a call for more studies. Biol Invasions 13:581-603. https://doi.org/10.1007/s10530-010-9851-3

Brown PR, Tuan NP, Singleton GR, Ha PTT, Hoa PT, Hue DT, Tan TQ, Tuat NV, Jacob J, Muller WJ (2006) Ecologically based management of rodents in the real world: applied to a mixed agroecosystem in Vietnam. Ecol Appl 16:2000-2010. https://doi.org/10.1890/ 1051-0761(2006)016[2000:EBMORI]2.0.CO;2

Butchart SHM, Walpole M, Collen B, Van Strien A, Scharlemann JPW, Almond REA, Baillie JEM, Bomhard B, Brown C, Bruno J, Carpenter KE, Carr GM, Chanson J, Chenery AM, Csirke J, Davidson NC, Dentener F, Foster M, Galli A, Galloway JN, Genovesi P, Gregory RD, Hockings M, Kapos V, Lamarque J, Leverington F, Loh J, McGeoch MA, McRae L, Minasyan A, Morcillo MH, Oldfield TEE, Pauly D, Quader S, Revenga C, Sauer JR, Skolnik B, Spear D, Stanwell-Smith D, Stuart SN, Symes A, Tierney M, Tyrrell TD, Vié J, Watson R (2010) Global biodiversity: indicators of recent declines. Science 328:1164-1168. https://doi.org/10.1126/science.1187512

Campbell KJ, Harper G, Hanson C, Keitt BS, Robinson S (2011) Review of feral cat eradications on islands. In: Veitch CR, Clout MN, Towns D (eds) Island Invasives: eradication and management. IUCN, Gland, pp 37-46

Capizzi D, Bertolino S, Mortelliti A (2014) Rating the rat: global patterns and research priorities in impacts and management of rodent pests. Mamm Rev 44:148-162. https://doi.org/10.1111/mam.12019

Courchamp F, Langlais M, Sugihara G (2000) Rabbits killing birds: modeling the hyperpredation process. J Anim Ecol 69:154-164. https://doi.org/10.1046/j.1365-2656.2000.00383.x

Courchamp F, Chapuis J, Pascal M (2003) Mammal invaders on islands: impact, control and control impact. Biol Rev 78:347-383. https:// doi.org/10.1017/s1464793102006061

Deplazes P, Van Knapen F, Schweiger A, Overgaauw PAM (2011) Role of pet dogs and cats in the transmission of helminthic zoonoses in Europe, with a focus on echinococcosis and toxocarosis. Vet Parasitol 182:41-53. https://doi.org/10.1016/j.vetpar.2011.07.014

Doherty TS, Bengsen AJ, Davis RA (2014) A critical review of habitat use by feral cats and key directions for future research and management. Wildl Res 41:435-446. https://doi.org/10.1071/WR14159

Doherty TS, Glen AS, Nimmo DG, Ritchie EG, Dickman CR (2016) Invasive predators and global biodiversity loss. PNAS 113:1126111265. https://doi.org/10.1073/pnas.1602480113

Doherty TS, Dickman CR, Johnson CN, Legge SM, Ritchie EG, Woinarski JCZ (2017) Impacts and management of feral cats Felis catus in Australia. Mamm Rev 47:83-97. https://doi.org/10.1111/ mam. 12080

Faraway JJ (2006) Extending the linear model with R: generalized linear, mixed effects and nonparametric regression models. Chapman \& Hall/CRC, Boca Raton

Ferreira JP, Leitao I, Santos-Reis M, Revilla E (2011) Human-related factors regulate the spatial ecology of domestic cats in sensitive areas for conservation. PLoS One 6:e25970. https://doi.org/10. 1371/journal.pone.0025970

Flockhart T, Norris R, Coe JB (2016) Predicting free-roaming cat population densities in urban areas. Anim Conserv 19:472-483. https:// doi.org/10.1111/acv.12264

Foley P, Foley JE, Levy JK, Paik T (2005) Analysis of the impact of trapneuter-return programs on populations of feral cats. J Am Vet Med Assoc 227:1775-1781. https://doi.org/10.2460/javma.2005.227. 1775

Gerhold RW, Jessup DA (2013) Zoonotic diseases associated with freeroaming cats. Zoonoses Public Health 60:189-195. https://doi.org/ $10.1111 / \mathrm{j} .1863-2378.2012 .01522 . x$ 
Horn JA, Mateus-Pinilla N, Warner RE, Heske EJ (2011) Home range, habitat use, and activity patterns of free-roaming domestic cats. J Wildl Manag 75:1177-1185. https://doi.org/10.1002/jwmg.145

Kagoshima Environmental Studies Program (2019) Feral cats in Amami: what cats asking us. Nanpo Shinsya, Kaghoshima (in Japanese)

Kagoshima Prefecture (2018) Monthly number of habu snake bites by municipality. http://www.pref.kagoshima.jp/aq04/chiiki/oshima/ kurashi/habu-joho.html. Accessed 12 March 2020 (in Japanese)

Kagoshima Prefecture (2019) The overview of Amami Islands. https:// www.pref.kagoshima.jp/aq01/chiiki/oshima/chiiki/zeniki/gaikyou/ h30amamigaikyou.html. Accessed 12 March 2020 (in Japanese)

Kays R, DeWan A (2004) Ecological impact of inside/outside house cats around a suburban nature preserve. Anim Conserv 7:273-283. https://doi.org/10.1017/S1367943004001489

Kays R, Dunn RR, Parsons AW, McDonald B, Perkins T, Powers SA, Shell L, McDonald JL, Cole H, Kikillus H, Woods L, Tindle H, Roetman P (2020) The small home ranges and large local ecological impacts of pet cats. Anim Conserv. https://doi.org/10.1111/acv. 12563

Legendre P, Legendre L (2012) Numerical ecology, 3rd English edition. Elsevier, Amsterdam

Leirs H, Lodal J, Knorr M (2004) Factors correlated with the presence of rodents on outdoor pig farms in Denmark and suggestions for management strategies. NJAS Wagening J Life Sci 52:145-161. https:// doi.org/10.1016/S1573-5214(04)80010-1

Lepczyk CA, Haman KH, Sizemore GC, Farmer C (2020) Quantifying the presence of feral cat colonies and Toxoplasma gondii in relation to bird conservation areas on O'ahu, Hawai'i. Conserv Sci Prac 2: e179. https://doi.org/10.1111/csp2.179

Lilith M, Calver M, Styles I, Garkaklis M (2006) Protecting wildlife from predation by owned domestic cats: application of a precautionary approach to the acceptability of proposed cat regulations. Austral Ecol 31:176-189. https://doi.org/10.1111/j.1442-9993.2006. 01582.x

Loss SR, Marra PP (2017) Population impacts of free-ranging domestic cats on mainland vertebrates. Front Ecol Environ 15:502-509. https://doi.org/10.1002/fee.1633

Mack RN, Simberloff D, Lonsdale WM, Evans H, Clout M, Bazzaz FA (2000) Biotic invasions: causes, epidemiology, global consequences, and control. Ecol Appl 10:689-710. https://doi.org/10. $2307 / 2641039$

Macpherson CNL (2013) The epidemiology and public health importance of toxocariasis: a zoonosis of global importance. Int $\mathrm{J}$ Parasitol 43:999-1008. https://doi.org/10.1016/j.ijpara.2013.07.004

Maeda T, Nakashita R, Shionosaki K, Fumio Y, Watari Y (2019) Predation on endangered species by human-subsidized domestic cats on Tokunoshima Island. Sci Rep 9:16200. https://doi.org/10. 1038/s41598-019-52472-3

Marra PP, Santella C (2016) Cat wars: the devastating consequences of a cuddly killer. Princeton University Press, Princeton

McGeoch MA, Butchart SHM, Spear D, Marais E, Kleynhans EJ, Symes A, Chanson J, Michael H (2010) Global indicators of biological invasion: species numbers, biodiversity impact and policy responses. Divers Distrib 16:95-108. https://doi.org/10.1111/j.14724642.2009.00633.x

Medina FM, Bonnaud E, Vidal E, Tershy BR, Zavaleta ES, Donlan CJ, Keitt BS, Corre ML, Horwath SV, Nogales M (2011) A global review of the impacts of invasive cats on island endangered vertebrates. Glob Chang Biol 17:3503-3510. https://doi.org/10.1111/j. 1365-2486.2011.02464.x

Ministry of the Environment (2018) World natural heritage recommended site comprehensive management plan in Amami-Oshima Island, Tokunoshima Island, Northern Okinawa-Jima Island and IriomoteJima Island. http://kyushu.env.go.jp/okinawa/amami-okinawa/ world-natural-heritage/plan/index.html. Accessed 12 March 2020 (in Japanese)
Morin DJ, Lesmeister DB, Nielsen CK, Schauber EM (2018) The truth about cats and dogs: landscape composition and human occupation mediate the distribution and potential impact of non-native carnivores. Glob Ecol Biogeogr 15:e00413. https://doi.org/10.1016/j. gecco.2018.e00413

Moseby KE, Stott J, Crisp H (2009) Movement patterns of feral predators in an arid environment - implications for control through poison baiting. Wildl Res 36:422-435. https://doi.org/10.1071/WR08098

Nagamine T (2011) Feral cat: the most familiar introduced mammal. In: Yamada F, Ikeda T, Ogura G (eds) Introduced mammals in Japan: management strategies and ecosystem conservation. Universty of Tokyo Press, Tokyo, pp 285-316 (in Japanese)

Nogales M, Vidal E, Medina FM, Bonnaud E, Tershy BR, Campbell KJ, Zavaleta ES (2013) Feral cats and biodiversity conservation: the urgent prioritization of island management. BioScience 63:804 810. https://doi.org/10.1525/bio.2013.63.10.7

Oppel S, Beaven BM, Bolton M, Vickery J, Bodey TW (2011) Eradication of invasive mammals on islands inhabited by humans and domestic animals. Conserv Biol 25:232-240. https://doi.org/10. 1111/j.1523-1739.2010.01601.x

Ota H (1998) Geographic patterns of endemism and speciation in amphibians and reptiles of the Ryukyu Archipelago, Japan, with special reference to their paleogeographical implications. Res Popul Ecol 40:189-204. https://doi.org/10.1007/BF02763404

Pierpaoli M, Biro ZS, Herrmann M, Hupe K, Fernandes M, Ragni B, Szemethy L, Randi E (2003) Genetic distinction of wildcat (Felis silvestris) populations in Europe, and hybridization with domestic cats in Hungary. Mol Ecol 12:2585-2598. https://doi.org/10.1046/j. 1365-294x.2003.01939.x

Pillay KR, Streicher J, Downs CT (2018) Home range and habitat use of feral cats in an urban mosaic in Pietermaritzburg, KwaZulu-Natal, South Africa. Urban Ecosyst 21:999-1009. https://doi.org/10.1007/ s11252-018-0766-6

Piquet JC, Baumgartner ES, Medina FM, Díaz-Luis N, Sevilla J, López H, Nogales M, López-Darias M (2019) A resource-efficient procedure to improve planning of invasive cat management on inhabited islets. Biol Invasions 21:1817-1831. https://doi.org/10.1007/ s10530-019-01941-x

Ringma J, Legge S, Woinarsli JCZ, Radford JQ, Wintle B, Bentley J, Burbidge AA, Copley P, Dexter N, Dickman CR, Gillespie GR, Hill B, Johnson CN, Kanowski J, Letnic M, Manning A, Menkhorst P, Mitchell N, Morris K, Moseby K, Page M, Palmer R, Bode M (2019) Systematic planning can rapidly close the protection gap in Australian mammal havens. Conserv Lett 12:e12611. https://doi. org $/ 10.1111 /$ conl.12611

Rosario L, Soledad FM, Regino C (2015) Wild small mammals in intensive milk cattle and swine production systems. Agric Ecosyst Environ 202:251-259. https://doi.org/10.1016/j.agee.2015.01.003

Sawanobori R (2019) Feral cat issue in Tokunoshima Island; II. Management by the Ministry of Environment. In: Kagoshima Environmental Studies Program (ed) Feral cats in Amami Islands Nanpo-shinsya, Kagoshima, pp 120-126 (in Japanese)

Spotte S (2014) Free-ranging cats: behavior, ecology, management. Wiley Blackwell, Oxford

Tennent J, Downs CT (2008) Abundance and home ranges of feral cats in an urban conservancy where there is supplemental feeding: a case study from South Africa. Afr Zool 43:218-229. https://doi.org/10. 1080/15627020.2008.11657238

Tenter AM, Heckeroth AR, Weiss LM (2000) Toxoplasma gondii: from animals to humans. Int J Parasitol 30:1217-1258. https://doi.org/10. 1016/s0020-7519(00)00124-7

Trouwborst A, McCormack PC, Martínez Camacho E, Young J (2020) Domestic cats and their impacts on biodiversity: a blind spot in the application of nature conservation law. People and Nature 2:235250. https://doi.org/10.1002/pan3.10073 
Vincent EC, Yoak AJ, O'Quin J, Garabed RB (2018) Comparison of field surveillance methods for and assessment of factors potentially associated with the presence of free-roaming cats in a mixed-urban environment. Am J Vet Res 79:745-754. https://doi.org/10.2460/ajvr. 79.7.745

Wilson AG, Lapen DR, Mitchell GW, Provencher JF, Wilson S (2020) Interaction of diet and habitat predicts Toxoplasma gondii infection rates in wild birds at a global scale. Glob Ecol Biogeogr 29:11891198. https://doi.org/10.1111/geb.13096

Woinarski JCZ, Woolley LA, Garnett ST, Legge SM, Murphy BP, Lawes MJ, Comer S, Dickman CR, Doherty TS, Edwards G, Nankivill A, Palmer R, Paton D (2017) Compilation and traits of Australian bird species killed by cats. Biol Conserv 216:1-9. https://doi.org/10. 1016/j.biocon.2017.09.017

Woolley LA, Geyle HM, Murphy BP, Legge SM, Palmer R, Dickman CR, Augusteyn J, Comer S, Doherty TS, Eager C, Edwards G, Harley DKP, Leiper I, McDonald PJ, McGregor HW, Moseby KE, Myers C, Read JL, Riley J, Stokeld D, Turpin JM, Woinarski JCZ (2019) Introduced cats Felis catus eating a continental fauna: inventory and traits of Australian mammal species killed. Mammal Rev 49:354-368. https://doi.org/10.1111/mam.12167

Publisher's note Springer Nature remains neutral with regard to jurisdictional claims in published maps and institutional affiliations. 